SMOKING

\title{
Expression of ErbB receptors and mucins in the airways of long term current smokers
}

\author{
R A O'Donnell, A Richter, J Ward, G Angco, A Mehta, K Rousseau, D M Swallow, S T Holgate, \\ R Djukanovic, D E Davies, S J Wilson
}

Thorax 2004;59:1032-1040. doi: 10.1136/thx.2004.028043

See end of article for authors' affiliations

.....................

Correspondence to: Dr D E Davies, The Brooke Laboratories, Division of Infection, Inflammation and Repair, School of Medicine, Southampton General Hospital,

Southampton, SO16 6YD, UK; donnad@soton.ac.uk

Received 12 May 2004 Accepted 23 August 2004
Background: Airway epithelial goblet cell hyperplasia is known to occur in chronic smokers. Although the epidermal growth factor receptor has been implicated in this process, neither ErbB receptor expression nor the mucosecretory phenotype of the epithelium have been characterised in current smokers.

Methods: Bronchial biopsies obtained from non-smokers $(n=10)$ and current smokers, with or without chronic obstructive pulmonary disease $(n=51)$, were examined immunohistochemically to measure the expression of epidermal growth factor receptor, ErbB2, ErbB3, ErbB4 and mucin subtypes (MUC2, MUC5AC and MUC5B) in the bronchial epithelium. The results were correlated with neutrophil counts measured in the airway wall and induced sputum.

Results: Epidermal growth factor receptor, ErbB3 and MUC5AC expression, in addition to PAS staining, were significantly increased in all smokers compared with non-smokers, irrespective of the presence of chronic obstructive pulmonary disease. MUC5AC expression was significantly associated with both PAS staining and ErbB3 expression; no correlation was observed between either mucin or ErbB receptor expression and neutrophil counts.

Conclusions: The results suggest that long term current smoking induces enhanced epidermal growth factor receptor, ErbB3, and MUC5AC expression in vivo; these increases are not associated with the presence of neutrophilic inflammation. ErbB receptors may contribute to epithelial responses to cigarette smoke.
7 oblet cell hyperplasia and metaplasia are well established hallmarks of the airways of cigarette smokers, with and without chronic obstructive pulmonary disease (COPD). ${ }^{12}$ In these subjects, goblet cells become more numerous and more evenly distributed across the spectrum of airway size. ${ }^{3}$ These changes, in combination with submucosal gland hypertrophy, lead to pathological mucus overproduction.

Enhanced epithelial mucin expression is believed to be the rate limiting step for goblet cell metaplasia. ${ }^{5}$ Four gel forming mucins (MUC2, MUC5AC, MUC5B and the recently dis-

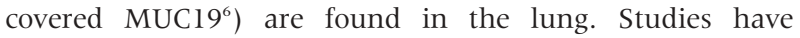
suggested that MUC5AC is the predominant secreted mucin of the bronchial epithelium while MUC2 and MUC5B are expressed also, but in lower amounts, and MUC5B is the main product of submucosal glands. ${ }^{78}$ Experimental evidence suggests that bronchial epithelial expression of MUC2, ${ }^{9}$ MUC5AC, ${ }^{10}$ and MUC5B ${ }^{11}$ may be augmented by inflammatory stimuli and enhanced MUC5AC expression has been associated with smoking. ${ }^{12}{ }^{13}$ Activated neutrophils also have the ability to induce epithelial MUC5AC expression. ${ }^{14}{ }^{15}$ Neutrophils are key effector cells in COPD and are consistently raised in the sputum of smokers with this disease, ${ }^{16-18}$ suggesting a possible link between neutrophilic airway inflammation and epithelial goblet metaplasia in COPD. However, to date, no quantitative comparisons have been performed of airway mucin protein expression in nonsmokers and long term current smokers with or without COPD, nor of their relationship to airway neutrophilia.

In vitro and in vivo models of oxidant induced airway epithelial injury have shown a link between the epidermal growth factor receptor (EGFR, ErbBl) and mucin expression. ${ }^{13}{ }^{15}$ The EGFR is the prototype member of a structurally homologous family of transmembrane receptor tyrosine kinases that also comprises ErbB2, ErbB3, and ErbB4. Ligand binding stabilises the EGFR in a dimeric form comprising either EGFR homodimers or EGFR/ErbB heterodimers involving one of the other members of the ErbB family (reviewed by Davies et $a l^{19}$ ). The phenomenon of heterodimerisation allows recruitment of the intracellular signalling moieties used by both receptor types involved, thus increasing the repertoire of activated intracellular messengers and helping to explain the pleiotropic effects of the EGF family..$^{20}$ There is much in vitro and in vivo evidence that the EGFR is intimately involved in normal epithelial maintenance and repair, however its dysregulation leads to induction of hyperproliferative and neoplastic conditions. ${ }^{19}$

EGFR, ErbB2, and ErbB3 are all expressed in the bronchial epithelium. ${ }^{21}$ Although previous reports have shown that cigarette smoking augments EGFR expression in human bronchial epithelium, ${ }^{22}$ the expression of other ErbB receptors in current smokers with or without COPD has never been investigated. We therefore hypothesised that increased airway expression of several members of the ErbB receptor family occurs in response to cigarette smoking and that this is associated with increased mucin expression and severity of disease. To test this we compared bronchial epithelial expression of immunoreactive EGFR, ErbB2, ErbB3, ErbB4, MUC2, MUC5AC, and MUC5B in a cohort of long term current smokers with and without COPD, and non-smoking controls. By examining the relationship between ErbB receptor expression and mucin expression, we looked for evidence to support the role of EGFR/ErbB receptors in the development of epithelial goblet cell metaplasia in vivo. We also looked for evidence to support a role for neutrophilic inflammation in the development of epithelial goblet cell metaplasia by examining the relationship between ErbB receptors, mucins, and neutrophil numbers in vivo.

Abbreviations: EGFR, epidermal growth factor receptor 
Table 1 Clinical characteristics of the five subject groups

\begin{tabular}{|c|c|c|c|c|c|}
\hline & $\begin{array}{l}\text { Non-smokers } \\
(\mathrm{n}=10)\end{array}$ & $\begin{array}{l}\text { Healthy smokers } \\
(\mathrm{n}=11)\end{array}$ & $\begin{array}{l}\text { Stage } 0 \text { COPD } \\
(\mathrm{n}=17)\end{array}$ & $\begin{array}{l}\text { Stage I COPD } \\
(n=9)\end{array}$ & $\begin{array}{l}\text { Stage II COPD } \\
(n=14)\end{array}$ \\
\hline$M / F$ & $4 / 6$ & $7 / 4$ & $11 / 6$ & $5 / 4$ & $10 / 4$ \\
\hline Age (years) & $51(7)$ & $45(12)$ & $50(7)$ & $57(7)$ & $55(7)$ \\
\hline Pack years & 0 & 40 (15) & 43 (19) & 42 (12) & $54(14) \S$ \\
\hline Current smoking (cigs/day) & 0 & $18(6)$ & $24(11)$ & $17(5)$ & $24(10)$ \\
\hline $\mathrm{FEV}_{1}(\%)$ & $111(12)$ & $102(8)$ & 99 (14) & $91(7)$ & $54(15)^{*}$ \\
\hline $\mathrm{FEV}_{1} / \mathrm{FVC}$ & $77(5)$ & $80(5)$ & $75(3)$ & $66(3) \dagger$ & $55(11) \dagger$ \\
\hline $\operatorname{TLCO}(\%)$ & $84(12.1)$ & $74(12)$ & $63(10.0)$ & $66(18)$ & $57(15) \ddagger$ \\
\hline
\end{tabular}

All data are shown as mean (SD). The data were analysed by ANOVA followed by the Scheffe examination.

$\mathrm{FEV}_{1}$, forced expiratory volume in 1 second; FVC, forced vital capacity; TLCO, carbon monoxide transfer factor.

${ }^{*} \mathrm{p}<0.001 v$ each of the other groups.

tp $<0.05 v$ non-smokers, healthy smokers, and those with stage 0 COPD.

士p $<0.05 v$ non-smokers and healthy smokers.

$\S p<0.05 v$ healthy smokers.

Ip $<0.05 v$ non-smokers.

\section{METHODS}

The study was approved by the Southampton University and General Hospitals ethics committee and volunteers gave their written informed consent. Most of the volunteers had also taken part in another recently published study comparing neutrophilic airway inflammation with emphysema severity. ${ }^{23}$

\section{Clinical assessment}

Detailed clinical history and physical examination were performed. Past smoking history was measured in pack years and current smoking history was expressed as the number of cigarettes currently being smoked per day (number smoked the day before the bronchoscopic examination). Quality of life was assessed using the St George's Respiratory Disease Questionnaire (SGRQ). ${ }^{24}$ Lung function testing consisted of spirometry carried out according to ATS guidelines, ${ }^{25}$ flowvolume loop, measurement of the residual volume to total lung capacity ratio, and carbon monoxide gas transfer factor (TLCO). Bronchodilator responsiveness to $400 \mu \mathrm{g}$ albuterol was measured and post bronchodilator spirometry values were recorded. Histamine bronchial provocation challenge was carried out as reported previously. ${ }^{26}$ To ensure the absence of subclinical emphysema in the healthy smoker group, HRCT scans (Hi-speed CTi scanner, General Electric) were performed at $10 \mathrm{~mm}$ intervals with $1 \mathrm{~mm}$ collimation on full inspiration and expiration. Scanning voltage was $140 \mathrm{kV}$ and current was $250 \mathrm{~mA}$. Hard copy images were photographed at a window level of $-650 \mathrm{HU}$ and a window width of $1500 \mathrm{HU}$. The scans were evaluated qualitatively for the presence of emphysema by a blinded consultant radiologist.

\section{Bronchoscopy and immunostaining}

Bronchoscopic examination was conducted according to approved international guidelines. ${ }^{27}$ Endobronchial biopsy specimens were taken from the middle lobe and right lower lobe and processed into glycol methacrylate (GMA) resin. ${ }^{28}$ Two micron sections of the resin embedded tissue were cut, coded, and immunostained. The following anti-ErbB antibodies were used: anti-EGFR 1:800; anti-ErbB2 1:20; anti-ErbB3 1:20; ${ }^{21} 29$ and anti-ErbB4 1:50. ${ }^{30}$ Each anti-ErbB antibody is specific for an individual ErbB receptor and does not crossreact with other members of the ErbB family. The antimucin antibodies used were anti-MUC5AC 1:400 clone $21 \mathrm{Ml}$ that binds the carboxy-terminal region of MUC5AC (a gift from Professor J M Bara ${ }^{31}$ ); anti-MUC2 1:20 that binds the tandem repeat region of MUC $2 ;^{32}$ and anti-MUC5B (1:20 hybridoma culture supernatant prepared in the London laboratory) that binds the centrally located repeated cysteine domains of MUC5B. ${ }^{33}$ All three antimucin antibodies are specific for their respective mucins and are not believed to crossreact with other mucins. ${ }^{31-33}$ Neutrophils were detected using an antineutrophil elastase antibody ${ }^{34}$ (Dako, Cambridge, UK). Isotype matched antibody controls were routinely used and were negative in all cases. In addition, sections were cut and stained with Periodic acid-Schiff (PAS) to quantify goblet cell numbers as previously described. ${ }^{35}$ Double staining for ErbB3 and PAS was performed to identify ErbB3/mucin co-localisation by following the standard immunohistochemistry protocol for ErbB3 but, instead of the final counterstaining step, the PAS technique was applied. Quantification of ErbB and mucin immunostaining in the epithelium was performed according to a previously described protocol $^{36}$ with the assistance of computerised image analysis (Image Associates, Bicester, UK) and expressed as a percentage of the total epithelial area. Positively stained neutrophils were counted in the epithelium and submucosa using a light microscope. Cell counts were expressed per $\mathrm{mm}^{2}$ submucosal area and $\mathrm{mm}$ epithelial length, measured by computerised image analysis. Epithelial cells staining positively for PAS were counted and expressed as a percentage of the total number of epithelial cells.

\section{Measurement of sputum neutrophil counts}

Sputum induction was achieved by the inhalation of aerosolised hypertonic saline $(4.5 \%))^{37}$ the induction time was kept constant at 20 minutes for all subjects. Unselected sputum was processed as described previously ${ }^{37}$ and cytospins were prepared and coded for total and differential cell counting. This involved counting 600 cells in each cytospin by an observer who was blinded to the code. The mean of two cytospin cell counts was used for analysis. Sputum neutrophils were expressed as a percentage of all inflammatory cells.

\section{Statistical analysis}

Statistical analysis was performed using SPSS version 10.0 software for Windows. Normally distributed data were compared between multiple groups by ANOVA followed by the Scheffe examination for individual comparisons. Comparisons between groups for cell counts and epithelial marker expression were made by the Kruskal-Wallis test followed by the Mann-Whitney test. Correlations were sought using Spearman's test. A $p$ value of $<0.05$ was regarded as statistically significant.

\section{RESULTS}

The 61 subjects who participated in the study were classified into the following groups: (1) healthy non-smoking control subjects $(n=10)$; (2) healthy smokers with normal lung function and no evidence of chronic bronchitis and 

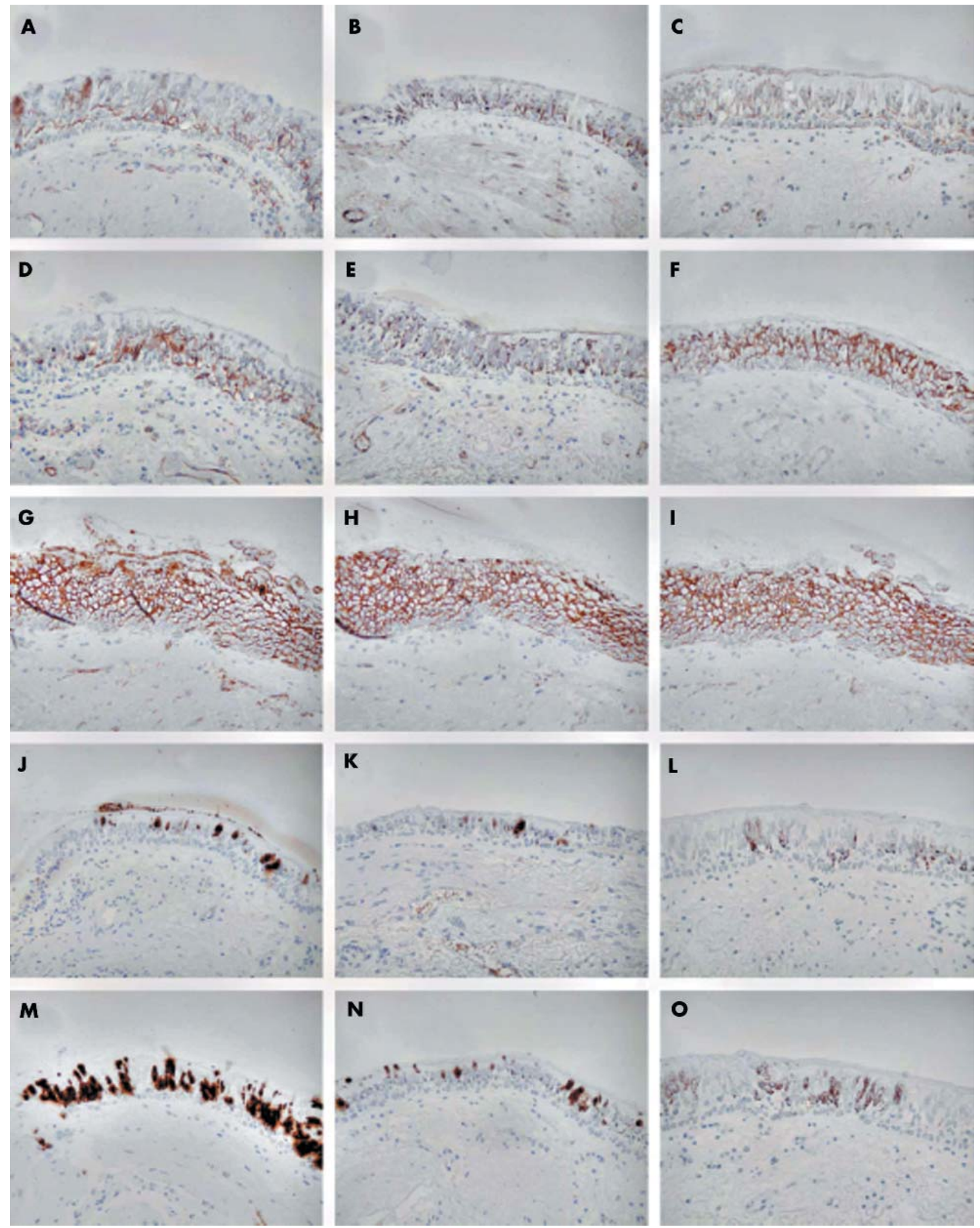

Figure 1 Typical patterns of EGFR (A, D), ErbB2 (B, E) and ErbB3 (C, F) staining in the bronchial epithelium of non-smokers (A-C) and subjects with COPD (D-F). Patterns of EGFR (G), ErbB2 (H) and ErbB3 (I) immunostaining in biopsies of smokers with squamous metaplasia (G-I) are also shown. Patterns of MUC5AC (J, M), MUC5B (K, N) and MUC2 (L, O) are shown in non-smokers (J-L) and subjects with COPD (M-O). In each plate the lumen is at the top of the section. Magnification $\times 20$. 
Table 2 Comparison of epithelial immunostaining for ErbB receptors, mucins and PAS in smokers $v$ nonsmokers

\begin{tabular}{lll}
\hline Epithelial marker & $\begin{array}{l}\text { Non-smokers } \\
(\mathbf{n}=10)\end{array}$ & $\begin{array}{l}\text { Smokers } \\
(\mathbf{n}=51)\end{array}$ \\
\hline EGFR & $2.8(0.8-7.0)$ & $5.8(0.3-22.3)^{\star}$ \\
ErbB2 & $1.3(0-5.4)$ & $2.5(0.1-9)$ \\
ErbB3 & $5.5(1.0-19.0)$ & $14.7(4-37.3) \ddagger$ \\
ErbB4 & $0.2(0.03-1.9)$ & $0.7(0-2.3)$ \\
MUC2 & $0.1(0-1.1)$ & $0.7(0-7.6)$ \\
MUC5B & $1.2(0-8.1)$ & $0.9(0-13.4)$ \\
MUC5AC & $3.3(1.1-11.7)$ & $24.7(3.5-49.3) \ddagger$ \\
MUC 5AC (\% +ve cells) & $7.7(0.4-21.4)$ & $32.5(0.4-59.6) \ddagger$ \\
PAS (\% +ve cells) & $13.9(0.5-19.2)$ & $26.8(0-64.1) \dagger$ \\
\hline
\end{tabular}

Data show median (range) percentage epithelial area immunostaining for ErbB receptor and mucin expression in bronchial biopsies of nonsmokers and smokers. The bottom two lines of the table show the percentage of total epithelial cell numbers that were positive for MUC5AC and PAS. Data were analysed using the Mann-Whitney test. ${ }^{*} \mathrm{p}<0.05 ; \mathrm{p} p<0.01 ; \neq \mathrm{p}<0.001$.

emphysema $(\mathrm{n}=11)$; (3) stage 0 COPD (smokers with chronic bronchitis but normal spirometry and normal HRCT, $\mathrm{n}=17$ ); (4) stage I COPD (smokers with mild airflow limitation (forced expiratory volume in 1 second $\left(\mathrm{FEV}_{\mathrm{l}}\right)$ $>80 \%$ predicted and $\mathrm{FEV}_{1} /$ forced vital capacity (FVC) $<70 \%$, $\mathrm{n}=9$ ); and (5) stage II COPD (smokers with $\mathrm{FEV}_{1}<80 \%$ and $\mathrm{FEV}_{1} / \mathrm{FVC}<70 \%, \mathrm{n}=14$ ). The clinical details of each group are shown in table 1 . All of the smokers in the study were current smokers. Of the 23 smokers with stage I or II COPD, 17 had symptoms of chronic bronchitis. None of the volunteers were atopic, none showed significant (>15\%) bronchodilator reversibility, and all had normal responsiveness to histamine. None of the subjects had a history of any disease other than COPD. All had been free of chest infections and had not had corticosteroid therapy for at least 3 months. Furthermore, none of the COPD subjects had ever been on inhaled corticosteroids.

\section{Epithelial ErbB receptor immunostaining}

Immunohistochemical analysis of normal airway mucosa revealed positive staining for EGFR, ErbB2 and ErbB3 in bronchial epithelium, submucosal glands and vascular endothelium; ErbB4 immunostaining was barely detectable (not shown). Within the bronchial epithelium, immunostaining was associated with the epithelial cell membranes and was most marked at the lower lateral junctions between columnar cells and their junctions with basal cells (fig lA-C); immunostaining for ErbB2 was weaker than for EGFR or ErbB3, as previously described. ${ }^{21}$ A similar pattern of ErbB immunostaining was observed in morphologically normal epithelium of biopsy specimens from smokers except that staining tended to extend closer to the apical surface (fig lDF). Both ciliated and goblet cells were positive for EGFR and ErbB3 immunostaining. In 48 of the 63 subjects additional intracytoplasmic immunostaining for the EGFR was also observed in some epithelial goblet cells; this did not follow any pattern of disease severity and was observed in six of the 12 non-smokers. Occasionally, biopsies showed a low level of positive immunostaining for ErbB4 but, in general, immunostaining was barely detectable. The biopsies of some smokers also contained areas of squamous metaplasia where uniform
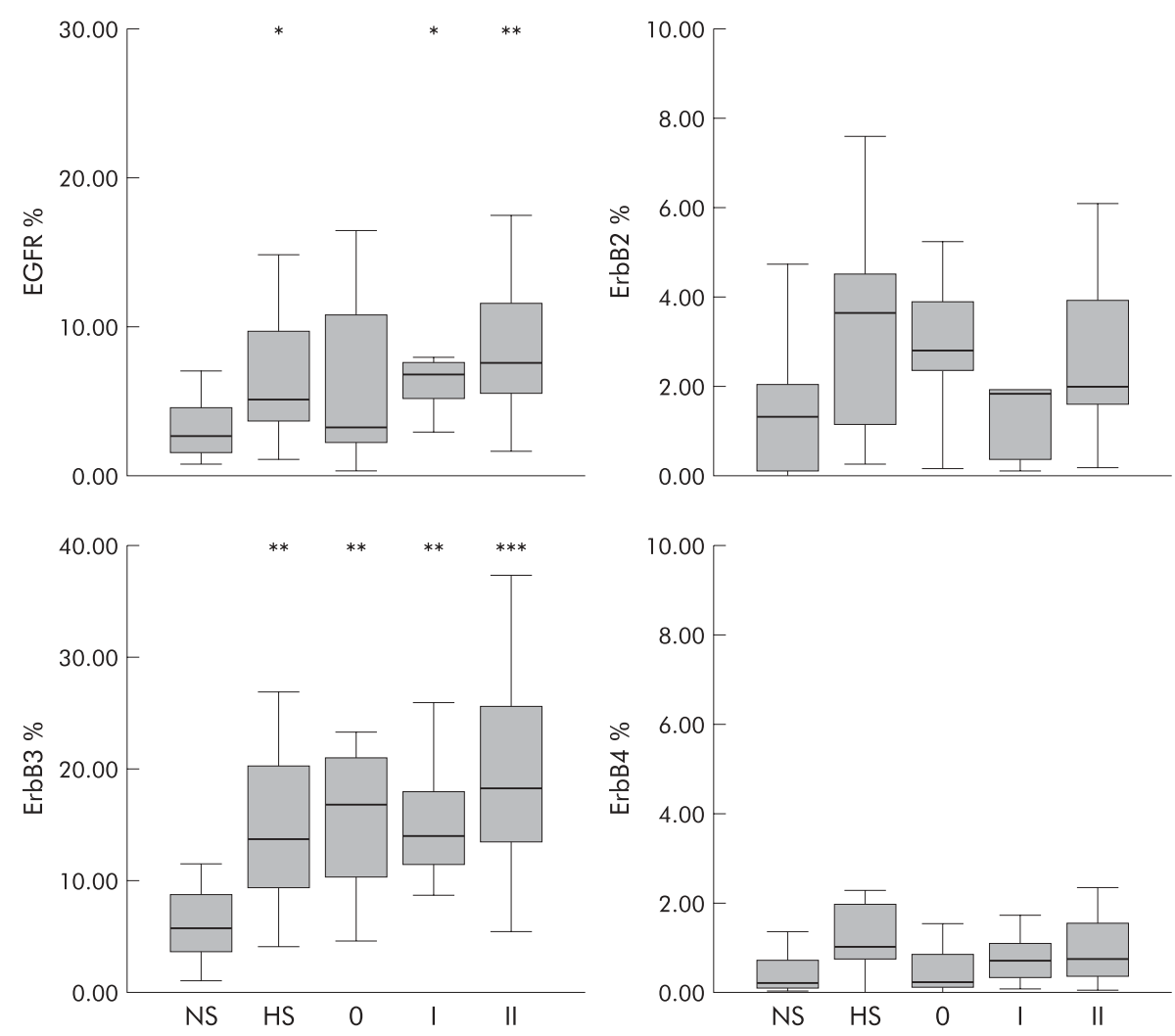

Figure 2 Analysis of ErbB receptor expression in bronchial epithelium of non-smokers versus current smokers without or with COPD. The box and whisker plots show median, range and interquartile ranges of the percentages of the epithelial area staining with each antibody. The percentage area expressing EGFR was significantly increased in each smoker group (except stage 0 COPD) compared with non-smokers, and the percentage area expressing ErbB3 was significantly increased in all smoker groups compared with non-smokers. ErbB2 and ErbB4 expression did not differ significantly between smokers and non-smokers. NS, non-smokers $(n=10) ; H S$, healthy smokers $(n=11) ; 0$, stage 0 COPD $(n=17) ; l$, stage I COPD $(n=9) ; I I$, stage II COPD $(n=14) .{ }^{*} p<0.05 v N S ;{ }^{* *} p<0.01 v N S ;{ }^{* * *} p<0.001 v N S$. 

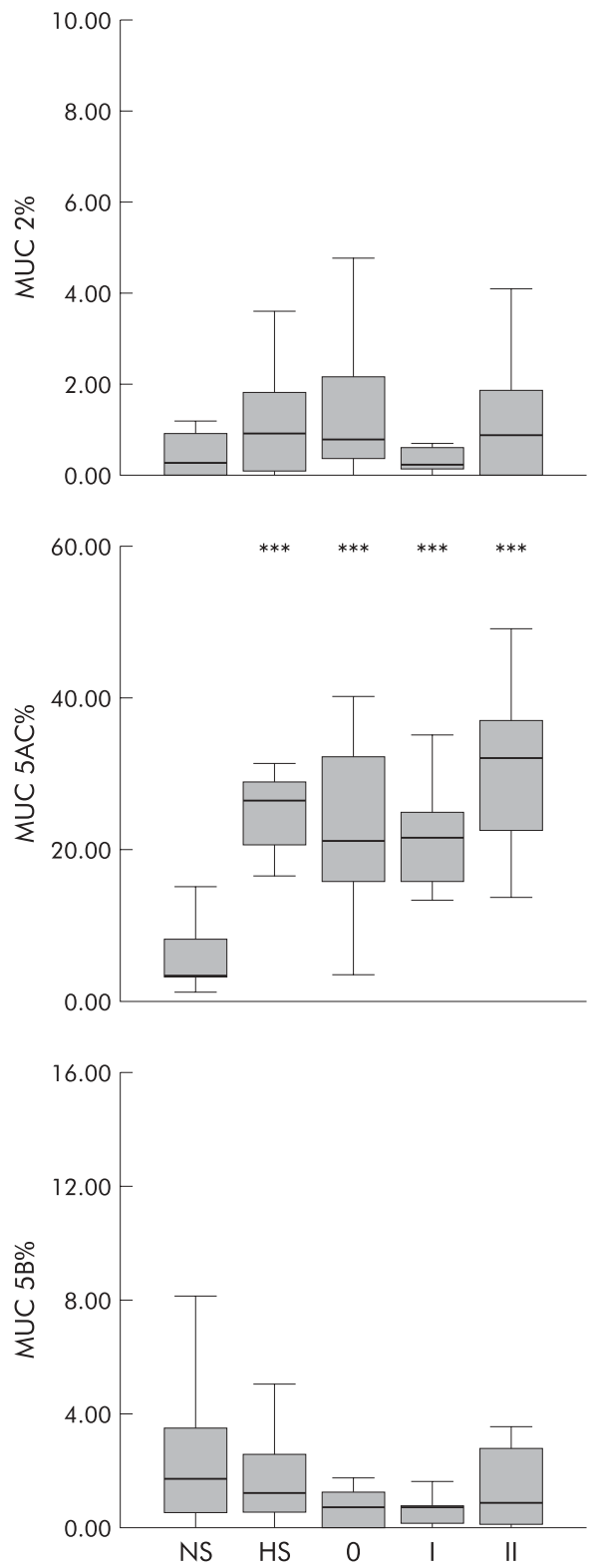

Figure 3 Comparison of the percentage of epithelial area expressing MUC2, MUC5AC, and MUC5B in bronchial epithelium of non-smokers v current smokers without or with COPD. MUC5AC expression was significantly higher in smokers than in non-smokers but did not differ significantly between healthy smokers and any of the COPD groups. There were no significant differences in the expression of either MUC2 or MUC5B between any of the subject groups. NS, non-smokers $(n=10)$; HS, healthy smokers $(n=11) ; 0$, stage 0 COPD $(n=17) ; l$, stage I COPD $(n=9)$; II, stage II COPD $(n=14) ;{ }^{* * *} p<0.001$.

membrane immunostaining was observed for the ErbB receptors (fig $1 \mathrm{G}-\mathrm{I}$ ). There were also regions of damaged epithelium that lacked columnar cells; in these areas ErbB staining was present at a similar intensity to that of neighbouring intact epithelium (data not shown).

Epithelial immunostaining for the various receptors was quantified (that is, the percentage epithelial area showing immunostaining) by computer aided image analysis. This involved measurements of immunostaining in areas of intact epithelium. Metaplastic or damaged epithelium were excluded from the analysis. Significantly increased immunostaining for EGFR $(\mathrm{p}<0.05)$ and ErbB3 $(\mathrm{p}<0.001)$ was observed in biopsy specimens from smokers compared with

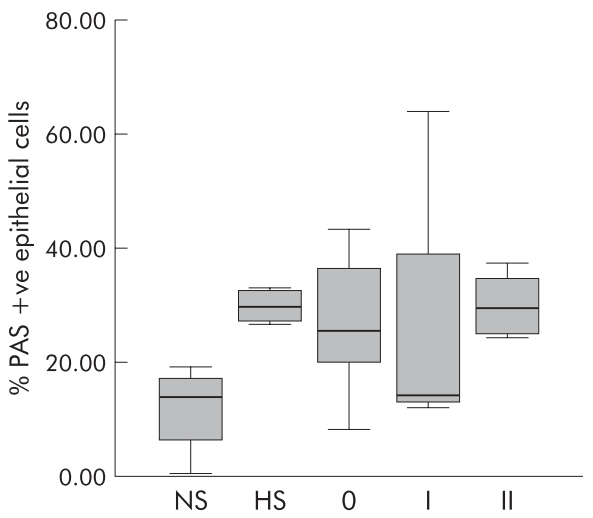

Figure 4 Comparison of PAS mucin staining in bronchial epithelium of non-smokers $v$ smokers without or with COPD. PAS positive cells, expressed as a percentage of the total number of epithelial cells, were significantly higher in all smoking groups than in non-smokers. There were no differences in PAS staining between healthy smokers and any of the COPD groups. NS, non-smokers $(n=10)$; HS, healthy smokers $(n=11) ; 0$, stage 0 COPD $(n=17) ; 1$, stage I COPD $(n=9) ; ~ I I$, stage II $\operatorname{COPD}(n=14) ;{ }^{* * *} p<0.001$.

non-smokers (table 2). Neither the percentage nor the pattern of staining for ErbB2 or ErbB4 differed significantly between smokers and non-smokers. Within the smoker group there was no significant difference in staining of any of the ErbB receptors between healthy smokers and smokers with COPD, irrespective of disease severity (fig 2). Moreover, when smokers were divided into those with and without chronic bronchitis there were no differences in ErbB receptor staining between either of the groups. No significant correlations were observed between epithelial ErbB receptor staining and pack year history, symptom scores, or lung function measurements of COPD severity. Current smoking habit, however, correlated weakly (but significantly) with staining of ErbB3 $(r=0.37, \mathrm{p}<0.05)$; no correlations were observed between current smoking and the percentage staining of the EGFR or ErbB2.

\section{Epithelial mucin immunostaining}

In normal airway mucosa positive immunostaining was observed with the MUC5AC, MUC5B and MUC2 antibodies. In all cases staining was predominantly intracytoplasmic and localised in goblet cells; no staining was observed in basal cells or ciliated cells. On visual inspection MUC5AC staining was the most prominent, present in the majority of goblet cells. In contrast, MUC5B and MUC2 staining was found in fewer goblet cells and was of lower intensity. In smokers there was a marked increase in goblet cells staining positively for MUC5AC compared with non-smokers $(p<0.001$, fig $1 \mathrm{~J}$, $\mathrm{M})$. Image analysis confirmed a large and highly significant increase in epithelial MUC5AC staining in smokers $(p<0.001$, table 2). The slight differences observed between smokers and non-smokers for MUC2 and MUC5B were not statistically significant. As had been observed for the ErbB receptors, there were no significant differences in the percentage epithelial area staining of any of the three mucins studied between healthy smokers and smokers with COPD (fig 3), and there were no differences in mucin staining between smokers with and without symptoms of chronic bronchitis. No correlations were found between epithelial mucin staining and current smoking habit, pack year history, symptom scores, or lung function measurements of COPD severity. PAS staining confirmed that goblet cell numbers were significantly increased in smokers compared with non-smokers $(\mathrm{p}<0.01)$, but there were no significant 

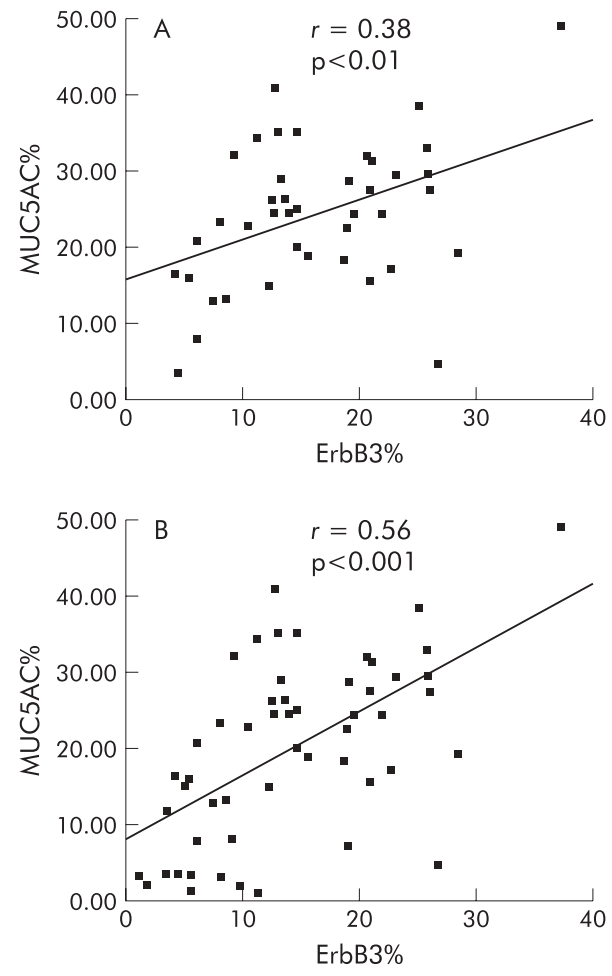

Figure 5 Scatter plots showing the correlation between MUC5AC and ErbB3 expression in bronchial epithelium in (A) smokers only, without or with COPD ( $r=0.38, p<0.01)$ and (B) all subjects (smokers and nonsmokers) $(r=0.56, p<0.001)$.

differences between healthy smokers and smokers with COPD, or between smokers with and without chronic bronchitis (fig 4). Significant correlations were observed between MUC5AC percentage epithelial area staining and the numbers of epithelial cells staining positively for both MUC5AC $(r=0.527, \mathrm{p}=0.000)$ and PAS $(r=0.43, \mathrm{p}<0.05)$.

The submucosal glands were strongly stained for MUC5B in all subjects, irrespective of disease. In contrast, MUC5AC and MUC2 showed very little glandular staining. No attempt was made to quantify this immunostaining because glands

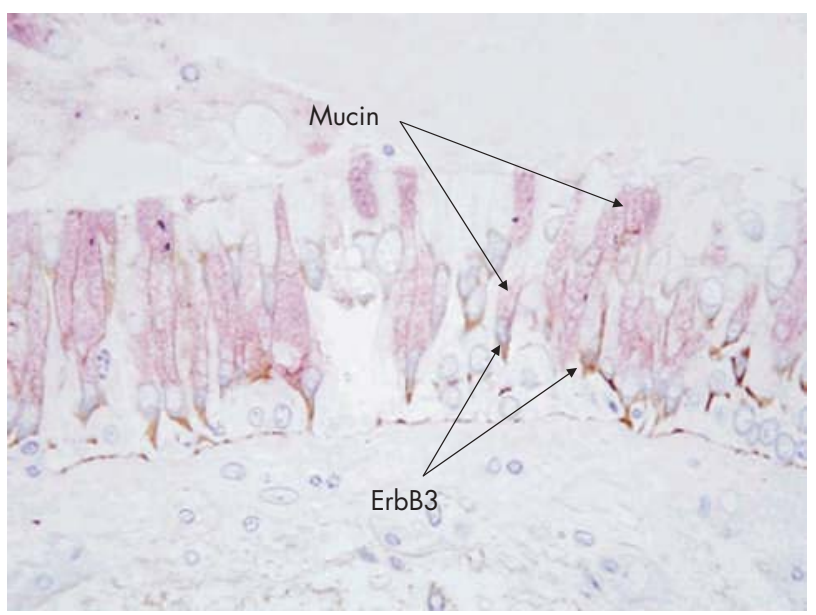

Figure 6 Co-localization of ErbB3 and mucin in goblet cells in a bronchial biopsy specimen taken from a smoker with COPD. The photomicrograph shows epithelial cells with intracellular mucin stained pink with Periodic acid-Schiff (PAS) and membrane bound ErbB3 stained brown with 3,3-diaminobenzidine (DAB). The lumen is at the top of the section. Magnification $\times 40$. were either only partially present, completely absent, or distorted by crush artefact in the majority of biopsy specimens.

\section{Correlation between ErbB and mucin expression}

Epithelial MUC5AC expression correlated significantly with ErbB3 expression either when all subjects were considered together $(r=0.56, \mathrm{p}<0.001)$ or when smokers were analysed on their own $(r=0.38, \mathrm{p}<0.01$; fig 5$)$. No other correlations were observed between any of the mucins and the other ErbB receptors.

\section{Co-localisation of ErbB3 and mucin staining}

Using the dual staining technique, staining for ErbB3 and PAS was found to co-localise to epithelial cells. Thus, cells positive for intracellular mucin demonstrated membrane expression of ErbB3, most marked at the lower lateral junctions of these cells (fig 6).

\section{Neutrophil counts}

Sputum, submucosal, and epithelial neutrophil counts are shown in table 3. Although no differences in neutrophil counts were observed between the clinical groups in either the bronchial submucosa or epithelium, relative sputum neutrophil counts were significantly higher in subjects with stage II COPD than in all the other groups except those with stage I COPD and correlated significantly in smokers with $\mathrm{FEV}_{1}$ impairment $(r=-0.52, \mathrm{p}<0.001)$. No correlations were observed between sputum, epithelial, or submucosal neutrophil counts and the percentage epithelial expression of any of the mucins or ErbB receptors studied.

\section{DISCUSSION}

To our knowledge, this study is the first to demonstrate in vivo that smoking increases MUC5AC expression in human bronchial epithelium and that epithelial ErbB3 expression is augmented in parallel and co-localised to mucin producing cells, thus suggesting a novel association between epithelial mucin expression and ErbB3 expression in chronic smokers. In addition, while we have confirmed previous reports ${ }^{13} 22$ that smoking enhances bronchial epithelial EGFR expression, our study is the first to carry out such an analysis in an extremely well characterised cohort of smokers, both with and without COPD. However, the results suggest that, in current smokers, enhanced expression of ErbB receptors occurs as a response to smoking, with no detectable relationship with disease severity. Whether the effects of current smoking obscure COPD related changes in ErbB receptor expression or whether there is genuinely no association between simple upregulation of these receptors and the pathophysiology of airflow obstruction in COPD remains uncertain. The increase in MUC5AC (but not MUC5B) that we have observed is consistent with the known increase in goblet cell numbers in the airways of smokers. ${ }^{2}$ However, similarly to ErbB receptor expression, the extent of epithelial MUC5AC expression was similar in healthy smokers and COPD subjects, consistent with previous studies of goblet cell numbers in peripheral airways of symptomatic and asymptomatic smokers. ${ }^{38}$ Finally, the extent of MUC5AC expression showed no association with the severity of neutrophilic inflammation, suggesting that neutrophilic inflammation per se is not a key determinant of proximal airway goblet cell hyperplasia in cigarette smokers.

Increased MUC5AC expression has been linked experimentally with goblet cell metaplasia in COPD. In rat models, exposure to the cigarette smoke constituent acrolein or to cigarette smoke itself enhances airway epithelial MUC5AC expression. ${ }^{12}{ }^{13}$ In vitro, cigarette smoke and products of activated neutrophils both augment MUC5AC expression by 
Table 3 Neutrophil counts in sputum, bronchial epithelium, and submucosa in each of the clinical groups

\begin{tabular}{|c|c|c|c|c|c|}
\hline & Non-smokers & Healthy smokers & Stage 0 COPD & Stage I COPD & Stage II COPD \\
\hline Sputum (\%) & $42.8(16.1-54.5)$ & $46.0(30.7-67.9)$ & $50.9(25.1-66.9)$ & 54.7 (26.9-70.7) & $68.2(44.6-78.1)^{*}+\ddagger$ \\
\hline Epithelium & $0.1(0-1.6)$ & $1.6(0-5.3)$ & $0.2(0-3.7)$ & $0.3(0-3.1)$ & $0.6(0-5.6)$ \\
\hline Submucosa & $14.1(6.3-49.6)$ & $16.1(1.8-25.9)$ & $13.4(3.9-28.2)$ & $14.4(7.9-38.3)$ & $16.7(3.5-61)$ \\
\hline \multicolumn{6}{|c|}{ 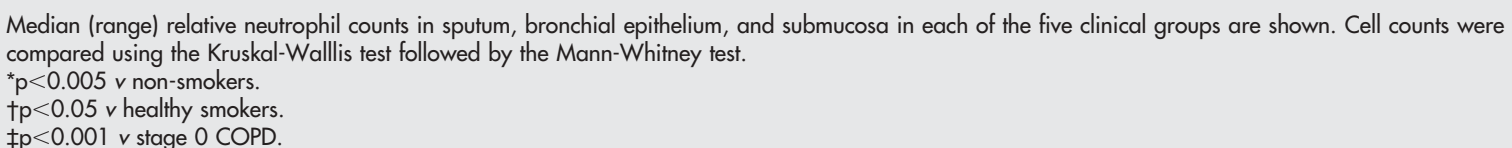 } \\
\hline
\end{tabular}

cultured epithelial cells. ${ }^{13-15} 39$ The current study provides in vivo confirmation that chronic smoking is associated with augmented bronchial epithelial expression of MUC5AC. Although there was no correlation with disease severity, the findings of the current study are confined to the proximal airways of current smokers in whom enhanced mucin expression may be secondary to the acute effects of smoking and less likely to impact upon airflow. The peripheral airways, on the other hand, are an important site of airflow obstruction in $\mathrm{COPD},{ }^{40}$ and enhanced mucus production is believed to contribute via both mechanical occlusion of the airway lumen ${ }^{41}$ and replacement of the surfactant lining, predisposing to airway collapse. ${ }^{42}$ The relative importance of MUC5AC, MUC2 or MUC5B-whether produced by the epithelium or submucosal glands-towards such changes in peripheral airway flow remains uncertain. Further studies are needed to ascertain whether our findings in the proximal airways reflect alterations in peripheral airway mucin expression in smokers.

Augmented epithelial expression of the EGFR has been reported previously in smokers ${ }^{22}$ and in asthma where it has been shown to be significantly associated with both disease severity and the extent of subepithelial remodelling changes. ${ }^{29} 3643$ In contrast, epithelial expression of EGFR showed no corresponding association with clinical markers of COPD disease severity, nor was there any difference between healthy smokers and subjects with COPD. However, since the findings of our study are limited to current smokers, we cannot exclude the possibility that the effects of persistent cigarette smoke exposure on the epithelium obscure a disease relationship in COPD. Moreover, as our immunohistochemical study provides only a snapshot view of EGFR protein expression, it remains possible that there is an underlying disease related difference in the extent of activation of these receptors. Recent work has shown that asthma is characterised by goblet cell hyperplasia associated with strong immunostaining for EGFR. ${ }^{44}$ Even though EGFR is increased in smokers, it is noteworthy that we found ErbB3 expression-rather than EGFR-correlated with MUC5AC expression. As epithelial expression of ErbB3 is unchanged in asthma, ${ }^{29}$ this may indicate a functionally relevant difference between the epithelium in asthma compared with smokers or it may simply reflect the use of different upstream mechanisms that converge on a common downstream signalling pathway leading to mucin gene expression. An example of such a common link may be phosphatidyl inositol 3-kinase (PI 3-kinase) which can be activated either by ErbB3 or by interleukin 13 which is strongly implicated in goblet cell hyperplasia in asthma. ${ }^{45}$

Of the ErbB receptors that are expressed by airway epithelial cells, expression of ErbB2 and ErbB4 were not different from normal in the epithelium of the smokers studied. However, their expression in the smoking groups showed more variability than either EGFR or ErbB3. The reason for this is unknown but, given the strong association of ErbB2 with malignant transformation, ${ }^{46}$ it may be speculated that higher ErbB2 expression in a subset of smokers might reflect other smoke related processes linked to the development of lung cancer. Expression of ErbB4 was absent or present at very low levels, as previously reported, ${ }^{21}$ and showed little change in response to cigarette smoking.

Previous studies both in animal models and in vitro have suggested the involvement of the EGFR in the regulation of mucin gene expression. ${ }^{1347} 48$ Our in vivo observation that both EGFR and ErbB3 are increased in the lungs of smokers, together with the significant association between the expression of ErbB3 and MUC5AC and the co-localisation of ErbB3 and mucin staining on the bronchial epithelium suggest, for the first time, that regulation of mucin expression may involve more than one member of the ErbB family and/or that activation of ErbB heterodimers may play a role in induction of goblet cell hyperplasia and/or metaplasia. Given the increase in both EGFR and ErbB3, EGFR/ErbB3 heterodimers could be the favoured pairing. However, even though expression of ErbB2 was unchanged, ErbB2/ErbB3 interactions may also be of importance, particularly as ErbB2 is the preferred dimerisation partner for the ErbB family. ${ }^{49}$

While correlations provide useful indicators of potential mechanisms, they do not necessarily imply cause and effect. We cannot exclude the possibility that increased ErbB3 expression is unconnected to enhanced mucin expression, rather that EGFR and ErbB3 each provide a distinct cytoprotective mechanism against noxious stimuli. Induction of a pro-survival response following exposure to cigarette smoke has been suggested in our in vitro studies where cytotoxicity measurements have shown that low doses of cigarette smoke extract cause lactate dehydrogenase activity to fall below that observed in untreated cells. ${ }^{50}$ As our study investigated only ErbB3 protein expression, it will be important to determine whether or not smoking promotes ErbB3 activation. Moreover, as protein expression may outlast receptor activation, any temporal relationship between growth factor activation and mucin gene transcription remains uncertain. Functional in vitro investigation is needed, not only to assess the effects of cigarette smoke on ErbB3 activity but also to elucidate whether inhibition of ErbB3 signalling decreases mucin mRNA expression and goblet cell hyperplasia in response to cigarette smoke.

Neutrophils and their products have been strongly implicated in the pathological changes linked to mucus overproduction. Of particular relevance to the present study is the demonstration that neutrophil derived oxidants have the ability to induce EGFR expression and to transactivate the EGFR leading to increased mucin gene expression. ${ }^{15}$ However, in our in vivo studies in human volunteers, epithelial EGFR and MUC5AC expression showed no association with the severity of neutrophilic inflammation, suggesting that the presence of neutrophilic inflammation per se is not a key determinant of proximal airway goblet cell hyperplasia in cigarette smokers. Furthermore, studies in cystic fibrosis $^{51}$ have failed to show any significant change in 
EGFR levels even though this disease is characterised by neutrophilic inflammation. In the present study the most striking differences in EGFR, ErbB3, and MUC5AC expression were observed between smokers and non-smokers, suggesting that cigarette smoke promotes epithelial goblet cell hyperplasia via alternative mechanisms. This could be a direct effect as cigarette smoke can induce ligand independent phosphorylation of EGFR. ${ }^{13}$ Alternative indirect mechanisms may include, for example, induction of autocrine epithelial expression of the EGFR ligands transforming growth factor $\alpha$ (TGF- $\alpha$ ) and amphiregulin, ${ }^{50}$ or activation of other inflammatory cells such as macrophages which are also known to produce TGF- $\alpha .{ }^{52}$ This does not exclude a role for neutrophils in other chronic lung diseases such as asthma and cystic fibrosis, nor does it exclude a contributory role for neutrophils in COPD where their actions in the proximal airways could possibly be overshadowed by the direct effects of cigarette smoke. Furthermore, as all subjects were free from respiratory infections for 3 months before the study, we cannot exclude the possibility that neutrophil-derived products released during an exacerbation may augment mucin gene expression and act as exocytotic stimuli for mucus hypersecretion from the goblet cells. Neutrophils are short lived inflammatory cells whose numbers in the airways do not necessarily reflect their level of activity. Comparisons between epithelial receptor and mucin expression and sputum markers of neutrophil activation such as myeloperoxidase (MPO), which is associated with COPD disease severity, ${ }^{53}$ may provide further insight into the relationship between neutrophilic inflammation in vivo and bronchial epithelial changes in smokers with COPD.

In conclusion, our study shows that bronchial epithelial expression of the EGFR, ErbB3 and MUC5AC are augmented in current smokers with and without COPD, suggesting that ErbB receptor heterodimerisation may be an important determinant of epithelial responses to cigarette smoke. Although our results do not point to any differences in either EGFR or ErbB3 protein levels in differentiating current smokers who remain healthy from those who develop COPD, this does not exclude underlying disease related differences in ErbB receptor activation. In addition, our results suggest that neutrophilic inflammation is not a key determinant of proximal airway goblet cell hyperplasia in cigarette smokers.

\section{ACKNOWLEDGEMENTS}

The authors acknowledge the Biomedical Imaging Unit, Southampton General Hospital for their assistance with sample analysis, members of EU consortium BMH4-CT98-3222 for the characterisation and provision of the antibody EU-MUC5Ba, and Dr Jacques Bara for kindly providing $21 \mathrm{Ml}$.

\section{Authors' affiliations \\ R A O'Donnell, A Richter, J Ward, G Angco, A Mehta, S T Holgate, \\ R Diukanovic, D E Davies, S J Wilson, Respiratory Cell and Molecular Biology, Division of Infection, Inflammation and Repair, University of Southampton, Southampton General Hospital, Southampton SO 16 6YD, UK}

K Rousseau, D M Swallow, Galton Laboratory, Biology Department, University College London, London NW1 2HE, UK

This work was supported by AstraZeneca.

\section{REFERENCES}

1 Mitchell RS, Stanford RE, Johnson JM, et al. The morphologic features of the bronchi, bronchioles, and alveoli in chronic airway obstruction: a clinicopathologic study. Am Rev Respir Dis 1976;1 14:137-45.

2 Hale KA, Ewing SL, Gosnell BA, et al. Lung disease in long-term cigarette smokers with and without chronic airflow obstruction. Am Rev Respir Dis $1984 ; 130: 716-21$.
3 Niewoehner DE, Kleinerman J, Rice DB. Pathologic changes in the peripheral airways of young cigarette smokers. N Engl J Med 1974;291:755-8

4 Cosio MG, Hale KA, Niewoehner DE. Morphologic and morphometric effects of prolonged cigarette smoking on the small airways. Am Rev Respir Dis 1980;122:265-71.

5 Rogers DF. Airway goblet cells: responsive and adaptable front-line defenders. Eur Respir J 1994;7:1690-706.

6 Chen Y, Zhao YH, Kalaslavadi TB, et al. Genome-wide search and identification of a novel gel-forming mucin MUC19/Muc19 in glandular tissues. Am J Respir Cell Mol Biol 2004;30:155-65.

7 Audie JP, Janin A, Porchet N, et al. Expression of human mucin genes in respiratory, digestive, and reproductive tracts ascertained by in situ hybridization. J Histochem Cytochem 1993;41:1479-85.

8 Groneberg DA, Eynott PR, Lim S, et al. Expression of respiratory mucins in fatal status asthmaticus and mild asthma. Histopathology 2002;40:367-73.

9 Levine SJ, Larivee P, Logun C, et al. Tumor necrosis factor-alpha induces mucin hypersecretion and MUC-2 gene expression by human airway epithelial cells. Am J Respir Cell Mol Biol 1995;12:196-204.

10 Louahed J, Toda M, Jen J, et al. Interleukin-9 upregulates mucus expression in the airways. Am J Respir Cell Mol Biol 2000;22:649-56.

11 Chen $\mathrm{Y}$, Thai $\mathrm{P}$, Zhao YH, et al. Stimulation of airway mucin gene expression by interleukin (IL)-17 through IL-6 paracrine/autocrine loop. J Biol Chem 2003;278: 17036-43.

12 Borchers MT, Wert SE, Leikauf GD. Acrolein-induced MUC5AC expression in rat airways. Am J Physiol 1998;274:L573-81.

13 Takeyama K, Jung B, Shim JJ, et al. Activation of epidermal growth factor receptors is responsible for mucin synthesis induced by cigarette smoke. Am J Physiol Lung Cell Mol Physiol 2001;280:L165-72.

14 Voynow JA, Young LR, Wang Y, et al. Neutrophil elastase increases MUC5AC mRNA and protein expression in respiratory epithelial cells. Am J Physiol 1999;276:L835-43.

15 Takeyama K, Dabbagh K, Jeong Shim J, et al. Oxidative stress causes mucin synthesis via transactivation of epidermal growth factor receptor: role of neutrophils. J Immunol 2000; 164:1546-52.

16 Keatings VM, Jatakanon A, Worsdell YM, et al. Effects of inhaled and oral glucocorticoids on inflammatory indices in asthma and COPD. Am J Respir Crit Care Med 1997; 155:542-8.

17 Peleman RA, Rytila PH, Kips JC, et al. The cellular composition of induced sputum in chronic obstructive pulmonary disease. Eur Respir $J$ 1999; 13:839-43.

18 Rutgers SR, Postma DS, ten Hacken $\mathrm{NH}$, et al. Ongoing airway inflammation in patients with COPD who do not currently smoke. Thorax 2000;55:12-8.

19 Davies DE, Polosa R, Puddicombe SM, et al. The epidermal growth factor receptor and its ligand family: their potential role in repair and remodelling in asthma. Allergy 1999;54:771-83.

20 Alroy I, Yarden Y. The ErbB signaling network in embryogenesis and oncogenesis: signal diversification through combinatorial ligand-receptor interactions. FEBS Lett 1997;410:83-6.

21 Polosa R, Prosperini G, Leir SH, et al. Expression of c-erbB receptors and ligands in human bronchial mucosa. Am J Respir Cell Mol Biol 1999;20:914-23

22 Barsky SH, Roth MD, Kleerup EC, et al. Histopathologic and molecular alterations in bronchial epithelium in habitual smokers of marijuana, cocaine, and/or tobacco. J Natl Cancer Inst 1998;90:1198-205.

23 O'Donnell RA, Peebles C, Ward JA, et al. Relationship between peripheral airway dysfunction, airway obstruction and neutrophilic inflammation in COPD. Thorax 2004;59:837-42.

24 Jones PW, Quirk FH, Baveystock CM, et al. A self-complete measure of health status for chronic airflow limitation. The St George's Respiratory Questionnaire. Am Rev Respir Dis 1992;145:1321-7.

25 Standardization of spirometry: 1987 update. Statement of the American Thoracic Society. Am Rev Respir Dis 1987; 136:1285-98.

26 Louis R, Shute J, Goldring K, et al. The effect of processing on inflammatory markers in induced sputum. Eur Respir J 1999;13:660-7.

27 Workshop summary and guidelines: investigative use of bronchoscopy, lavage, and bronchial biopsies in asthma and other airway diseases. J Allergy Clin Immunol 1991;88:808-14.

28 Britten KM, Howarth PH, Roche WR. Immunohistochemistry on resin sections: a comparison of resin embedding techniques for small mucosal biopsies. Biotechnic Histochem 1993;68:271-80.

29 Polosa R, Puddicombe SM, Krishna MT, et al. Expression of c-erbB receptors and ligands in the bronchial epithelium of asthmatic subjects. J Allergy Clin Immunol 2002;109:75-81.

30 Srinivasan R, Poulsom R, Hurst HC, et al. Expression of the c-erbB-4/HER4 protein and mRNA in normal human fetal and adult tissues and in a survey of nine solid tumour types. J Pathol 1998;185:236-45.

31 Bara J, Chastre E, Mahiou J, et al. Gastric M1 mucin, an early oncofetal marker of colon carcinogenesis, is encoded by the MUC5AC gene. Int J Cancer 1998;75:767-73

32 Xing PX, Prenzoska J, Layton GT, et al. Second-generation monoclonal antibodies to intestinal MUC2 peptide reactive with colon cancer. J Natl Cancer Inst 1992;84:699-703.

33 Rousseau K, Wickstrom C, Whitehouse DB, et al. New monoclonal antibodies to non-glycosylated domains of the secreted mucins MUC5B and MUC7. Hybrid Hybridomics 2003;22:293-9.

34 Pulford KA, Erber WN, Crick JA, et al. Use of monoclonal antibody against human neutrophil elastase in normal and leukaemic myeloid cells. J Clin Pathol 1988;41:853-60

35 McManus J. Histological demonstration of mucin after periodic acid. Nature 1946;158:202 
36 Puddicombe SM, Polosa R, Richter A, et al. Involvement of the epidermal growth factor receptor in epithelial repair in asthma. FASEB $J$ 2000;14:1362-74.

37 Louis $\mathbf{R}$, Lau LC, Bron AO, et al. The relationship between airways inflammation and asthma severity. Am J Respir Crit Care Med 2000;161:9-16.

38 Saetta M, Turato G, Baraldo S, et al. Goblet cell hyperplasia and epithelial inflammation in peripheral airways of smokers with both symptoms of chronic bronchitis and chronic airflow limitation. Am J Respir Crit Care Med 2000;161:1016-21.

39 Fischer B, Voynow J. Neutrophil elastase induces MUC5AC messenger RNA expression by an oxidant-dependent mechanism. Chest 2000;117(5 Suppl 1):317-20S.

40 Cosio M, Ghezzo H, Hogg JC, et al. The relations between structural changes in small airways and pulmonary- function tests. N Engl J Med 1978;298:1277-81.

41 Hogg JC, Macklem PT, Thurlbeck WM. Site and nature of airway obstruction in chronic obstructive lung disease. N Engl J Med 1968;278:1355-60.

42 Nagai A, West WW, Thurlbeck WM. The National Institutes of Health Intermittent Positive-Pressure Breathing trial: pathology studies. II. Correlation between morphologic findings, clinical findings, and evidence of expiratory air-flow obstruction. Am Rev Respir Dis 1985;132:946-53.

43 Amishima M, Munakata M, Nasuhara Y, et al. Expression of epidermal growth factor and epidermal growth factor receptor immunoreactivity in the asthmatic human airway. Am J Respir Crit Care Med 1998;157:1907-12.

44 Takeyama K, Fahy JV, Nadel JA. Relationship of epidermal growth factor receptors to goblet cell production in human bronchi. Am J Respir Crit Care Med 2001;163:511-6.
45 Atherton $\mathrm{HC}$, Jones G, Danahay H. IL-13-induced changes in the goblet cell density of human bronchial epithelial cell cultures: MAP kinase and phosphatidylinositol 3-kinase regulation. Am J Physiol Lung Cell Mol Physiol 2003;285: :730-9

46 Selvaggi G Scagliotti GV, Torri V, et al. HER-2/neu overexpression in patients with radically resected nonsmall cell lung carcinoma. Impact on longterm survival. Cancer 2002;94:2669-74.

47 Takeyama K, Dabbagh K, Lee HM, et al. Epidermal growth factor system regulates mucin roduction in airways. Proc Natl Acad Sci USA 1999:96:3081-6.

48 Lee HM, Takeyama K, Dabbagh K, et al. Agarose plug instillation causes goblet cell metaplasia by activating EGF receptors in rat airways. Am J Physiol Lung Cell Mol Physiol 2000;278:L185-92.

49 Graus-Porta D, Beerli RR, Daly JM, et al. ErbB-2, the preferred heterodimerization partner of all ErbB receptors, is a mediator of lateral signaling. EMBO J 1997; 16:1647-55.

50 Richter A, O'Donnell RA, Powell RM, et al. Autocrine ligands for the epidermal growth factor receptor mediate interleukin-8 release from bronchial epithelial cells in response to cigarette smoke. Am J Respir Cell Mol Biol 2002;27:85-90.

51 Hardie WD, Bejarano PA, Miller MA, et al. Immunolocalization of transforming growth factor alpha and epidermal growth factor receptor in lungs of patients with cystic fibrosis. Pediatr Dev Pathol 1999;2:415-23.

52 Madtes DK, Raines EW, Sakariassen KS, et al. Induction of transforming growth factor-alpha in activated human alveolar macrophages. Cell 1988;53:285-93

53 Hill AT, Bayley D, Stockley RA. The interrelationship of sputum inflammatory markers in patients with chronic bronchitis. Am J Respir Crit Care Med $1999 ; 160: 893-8$

\section{LUNG ALERT}

\section{Home environmental intervention benefits urban children with atopic asthma}

$\Delta$ Morgan WJ, Crain EF, Gruchalla RS, et al. Results of a home-based environmental intervention among urban children with asthma. N Engl J Med 2004;351:1068-80

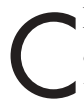

hildren with asthma who live in the inner city are exposed to multiple indoor allergens and environmental tobacco smoke in their homes. It is difficult to reduce these

triggers and previous studies have not shown any significant decrease in morbidity.

In this randomised controlled trial of an environmental intervention over 1 year, 937 children (age 5-11 years) with atopic asthma in seven major US cities were enrolled. Intervention included education and various behavioural and environmental modifications to reduce exposure to dust mites, tobacco smoke, cockroaches, pets, rodents, and mould. Home environmental exposures were assessed every 6 months and asthma related complications were assessed every 2 months during the intervention and for 1 year after the intervention. The results showed that there was a greater decline in the levels of dust mite allergens (Der $f \mathrm{l}$ and $\operatorname{Der} p \mathrm{l}$ ) and cockroach allergen (Bla $g$ l) in the intervention group. For every 2 week period the intervention group had fewer days with symptoms than did the control group, both during the intervention year $(3.39 v 4.20$ days, $\mathrm{p}<0.001)$ and in the year afterwards $(2.62 \vee 3.21$ days, $\mathrm{p}<0.001)$. Reductions in the level of cockroach allergen and house dust mite on the bedroom floor were significantly correlated with reduced complications of asthma $(\mathrm{p}<0.001)$, such as number of hospital admissions and the number of unscheduled visits to the emergency department or clinic for asthma.

This study shows that, among inner city children with atopic asthma, an individualised home based comprehensive environmental intervention decreases exposure to indoor allergens, including cockroach and house dust mite allergens, and results in reduced asthma associated morbidity. The estimated cost of the intervention was \$1500-2000 per child.

K S Srinivasan

Consultant Respiratory Physician, Princess Royal Hospital, Telford, UK; ks.srinivasan@prh.nhs.uk 